\title{
Letter to President George W. Bush
}

April 11, 2008

Forty-one years earlier, Rabbi Beerman addressed a letter to President Lyndon Johnson, requesting that his and Martha Beerman's taxes not be directed toward the war effort in Vietnam. Here in 2008, he requested that his and Joan Beerman's taxes not be directed toward the war effort in Iraq, but rather toward "works of healing and peace." His language is much the same in the two letters, although there is new language in the 2008 missive calling for the return of "our brave soldiers to their homes and families." This represents a key attitudinal shift in American society after Vietnam whereby US soldiers went from being perceived by many in negative termsas complicit in the war effort-to a new appreciation for the difficult plight in which they were placed and for the scars that war inflicted on them.

President George W. Bush

The White House

Washington, D.C.

April 11, 2008

Dear Mr. President:

My wife Joan and I have just paid our income tax for the year 2007. That portion of our tax which helps to sustain the war in Iraq has been paid involuntarily. We have no wish to support what we consider to be unjust. We should be happy to pay even a greater proportion of our income for works of healing and peace, but the acts of violence being perpetrated by our government violate our conscience. That portion of our tax that helps make these acts possible we pay under protest. 
We pray that you may have the courage and the wisdom to bring this war to a swift end, and return our brave soldiers to their homes and families.

Sincerely,

Leonard I. Beerman

\section{COMMENTARY BY NORMAN LEAR}

This letter to President George W. Bush is a perfect example of who Leonard Beerman was, as a man, and as a citizen. He was willing to put his money and morals on the line-and speak truth to power. Whatever the issue, the cause, the question, you never had to doubt where Leonard stood-he made his opinion known. Leonard was that man not because he saw it as a duty, but because being responsible was second nature to him.

Leonard Beerman was sweet-tempered and mild-mannered. One could call him reticent, unassuming-even shy perhaps_but underneath that there was a layer of wise conviction that placed him, from my point of view, in the Man of Steel category. Leonard's wisdom came with enormous courage and conviction. Who else, speaking on the Fourth of July at the All Saints Episcopal Church in Pasadena, would remind America that its "wanton use of power had abused others, killed, wounded or driven them into exile ... and was now abusing so many of its own citizens ... having organized all of the dominant workings of a society to move in total subservience to an economy that enriches the very few."

In another sermon, speaking of the Jewish people whom he had devoted his life to lead, he honored their generosity, endurance, and accomplishments, but then had the guts and temerity to refer to the now and then "chasm between their ideals and their deeds . . . in such contentious matters as Israel's treatment of the Palestinians and the continuing moral outrage of its occupation of the West Bank." That behavior, said the good rabbi, "threatened the ethical core of Israel's being."

In 1980, fearful of the mix of politics and religion emanating from televangelist Pat Robertson's 700 Club, Jerry Falwell's Moral Majority, and the like, I wanted to do something about it, and I needed advice. Of course I sought out Leonard Beerman and learned that, with his good friend George Regas, he had already been mounting a mainline church effort to counter the Religious Right.

"Stick to your last," Leonard advised me, and encouraged me to go after them with the tricks of my trade. People for the American Way grew out of a sixty-second public service announcement that followed my acceptance of Leonard's advice.

Wisdom, with courage and conviction, was freely dispensed by Leonard Beerman on a daily basis. I'm grateful that much of it is still available in his published sermons. 